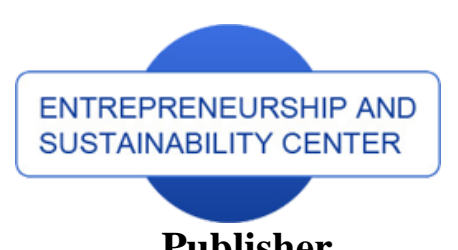

Publisher

http://jssidoi.org/esc/home

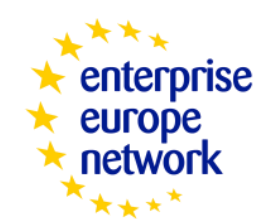

Business Support on Your Doorstep

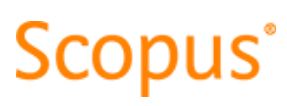

\title{
INNOVATION SECURITY OF CROSS-BORDER INNOVATIVE MILIEU*
}

\author{
Andrey S. Mikhaylov', Anna A. Mikhaylova², Oksana V. Savchina ${ }^{3}$ \\ 1,2 Immanuel Kant Baltic Federal University, A. Nevskogo str. 14, 236016, Kaliningrad, Russian Federation \\ ${ }^{2}$ RUDN University, Miklukho-Maklaya str. 6, 117198, Moscow, Russian Federation \\ E-mails: ${ }^{1}$ mikhailov.andrey@yahoo.com ${ }^{2}$ tikhonova.1989@mail.ru ; ${ }^{3}$ savchina_ovl@rudn.university
}

Received 15 July 2018; accepted 20 October 2018; published 30 December 2018

\begin{abstract}
Innovative milieu is an elusive networking scheme established within geospatial, socio-economic, institutional, and knowledge types of boundaries that enable the actors involved to excel in particular field(s) of activity. Generally these are high-tech sectors of the economy, the so called smart and creative industries that are highly reliant on human capital, knowledge, and competences. Gradual expansion of interregional and international ties increases the possibility for synergies, fostering network diversification and intra-regional overspecialisation all at the same time. Along with numerous positive externalities, such as avoidance of the cognitive lock-in effect, regional clusters of excellence become dependent on their external counterparts, either within national or international domain. This dependence is caused by utilization of shared science and technology facilities, interdependent production processes, complementary technologies, etc. Unforeseen circumstances, such as temporal economic sanctions and product embargo can affect the sustainability of the innovation activity in the region and create structural holes along the value chain. Regional innovation policy should account for possible threats to the regional as well as national innovation systems. In this paper we examine different scenarios for the development of innovative milieus across borders. The study draws upon cross-border cooperation initiatives of European border regions, featuring brief case study examples for each of the negative development scenarios identified. There are three major types of threats to innovation security of a border region determined: a) disintegration and decay, b) internal asymmetries, c) unilateral integration initiatives. The article concludes with policy recommendations on innovation security strategy for the borderland regions.
\end{abstract}

Keywords: innovation security; economic security; regional innovation system; cross-border cooperation; border region; borderland; innovation system vulnerability

Reference to this paper should be made as follows: Mikhaylov, A.S.; Mikhaylova A.A.; Savchina, O.V. 2018. Innovation security of crossborder innovative milieus, Entrepreneurship and Sustainability Issues 6(2): 754-766. http://doi.org/10.9770/jesi.2018.6.2(19)

JEL Classifications: O30, R10, F5

Additional disciplines: economic geography; political sciences

*The reported study was funded by Russian Science Foundation according to the research project 18-17-00112 "Ensuring economic security of Russia's western border regions in the conditions of geopolitical turbulence"; The publication has been prepared with the partial support of the "RUDN University Programme "5-100"》 


\section{Introduction}

The modern-day regional sustainable development is interlinked with innovation activity being the core of its long-term competitiveness. Taking the perspective of innovation economy region is not only being a party to the innovation process but also the defining environment of its implementation. Its favourability depends on many factors, such as the enabling institutional setup, the localization of specialized companies, the state of intraregional demand for innovation, the accumulation of strategic resources, the social integration of actors leading to formation of an innovative milieu, et cetera. The latter factor is often underestimated by policymakers due to its elusiveness. Although it sets the motion vector of the entire innovation economy via establishment of the constellations of competences - the interlinked 'clusters of competencies' (Niosi, 2000), the 'competence blocks' (Eliasson, 1996; Carlsson et al., 2002) or the 'ensembles of competences', as articulated by Maskell and Malmberg (1999) in their pursuit to grasp the substance of regional competitiveness. In this same logic the ideas on an inventive-enabling environment (i.e. 'creative field', 'creative space', 'creative milieu', 'regional collective learning', 'innovation ecosystem', etc. see a review of Mikhaylov, 2016) and the 'embeddedness' (Gertler et al., 2000; Oerlemans et al., 2001) of innovation are being developed. The basic framework behind these concepts is that the innovative context of the region is being formed from the interactions of heterogeneous regional actors, generated and defined by their internal aspirations to ensure the competitiveness of enterprises and a certain quality of life for individuals. This sustainable interactive communication, often being of 'untraded' and 'unintended' nature (Storper, 1995), results in the development of a shared vision over the innovative development, embodied in long-term strategy of regional clusters or the regional innovation system (RIS) as a whole. Acting as lex non scripta to local communities of innovation this development strategy should correlate the official regional policy but it not always does.

Despite the apparent region-wide benefits with regard to entrepreneurial consolidation (incl. entrepreneurial universities, innovative NGOs) and the existence of commonly accepted far-reaching development plan of the regional community innovation activity does not imply a full consistence with the long-term interests of the region's innovation sustainability per se, as was discussed earlier (Mikhaylova and Mikhaylov, 2015, 2016). Taking into account the dualistic nature of the influence of innovation - carrying possible negative externalities, unintended and disruptive consequences (Bergek et al., 2013; Hall and Martin, 2005), the region is interested not so much in innovations itself, as a result of innovation activities, but in the effects they impose on the regional system. Changes in the subsystems of the RIS caused by implemented innovations should coincide with the development objectives of the system as a whole and its individual subsystems. Moreover, it is expected that regionally 'brewed' innovations will be in demand by local economy, influencing the general socio-economic welfare. Yet, as it is reflected in numerous studies' results, the misbalance in innovation activity is typical to outlying, peripheral regions (e.g. studies in the scope of Russia held by Baburin and Zemtsov, 2014; Mikhaylova and Mikhaylov, 2016). Scholars note that being the state geo-economic outskirts, border and coastal regions do not follow the nation-wide development trends it terms of both the demography and economy (Melançon and Doloreux, 2013; Morrissey, 2015). Huggins and Johnston (2009), Lagendijk and Lorenzen (2007), Tödtling and Trippl (2005), and Virkkala (2007) further highlight the differences in innovation activity of regions. The peripheral location of the border and coastal regions increases vulnerability of their innovation systems to external exposure. Lack or incoherence of globally competitive industrial leaders - the growth nodes of the regional economy, absence of sufficient demand for innovation, low market capacity and other factors force local businesses, research centres, university labs and other actors to search for networking opportunities abroad. This makes the economy and the innovation activity of these regions volatile with regards to development objectives of neighbouring states and large market players, who set the development direction for the entire value-added network (incl. innovation driven networks). This leads to a dissonance between the regional strategic goals, as an 


\section{The International Journal}

ENTREPRENEURSHIP AND SUSTAINABILITY ISSUES

ISSN 2345-0282 (online) http://jssidoi.org/jesi/

2018 Volume 6 Number 2 (December)

http://doi.org/10.9770/jesi.2018.6.2(19)

element of the national system (incl. national innovation system - NIS), and the goals of individual economic entities or clusters at the regional level (i.e. RIS), which are fully aligned with the activities of the more influential players from outside. Moreover, the long-term sustainability of the regional innovative milieu is threatened by the variety of external factors, including the highly unstable political relations.

The objective of this study is to identify possible threats to regional innovation security in case of innovative milieus integration across national borders. In the next section we review background studies on regional innovation system with a focus on cross-border networking and the role of innovative milieu in regional development. Section 3 provides an overview of research methodology. Section 4 features a number of brief case studies on cross-border regional innovation systems that exhibit different development scenarios and feature the exposure to various threats for regional innovation security. The paper closes with some discussion and policy recommendations.

\section{Background and literature review}

Research on the nature and role of innovation in regional development received its most widespread attention in economic geography and regional studies. Significant influence over the innovation theory had the idea of geographic localization of innovation (Almeida and Kogut, 1997; Audretsch and Feldman, 2003; Feldman and Audretsch, 1996). It is reflected in a number of concepts that describe the spatially determined process of generation, implementation and diffusion of innovation focusing on actors' proximity and social embeddedness of the economy: innovation diffusion, knowledge spillover, absorptive capacity, et cetera. Common geographical location is said to ensure a coherent institutional, political and socio-cultural context for its participants. A variety of scientific approaches on this matter can be structured in two general categories: firstly, those, focusing on spatial networking, combining studies on the features of territorial distribution of productive forces in a region and the emergence of agglomeration effects (i.e. external economies) that contribute to innovation activity; secondly, dealing with contextual environment, explaining various aspects of regional environment formation and its influence over the innovation process.

The first approach is characterized by a shift in focus toward the study of interdependencies between the placement of productive forces and the innovative capacity of region's economy (e.g. the concepts of new industrial districts, innovation cluster, new industrial spaces, technology poles and others). Researchers articulate that spatial clustering of economic entities within the same geographical area (incl. cross-border area) contributes to growth of their innovative activity, since it facilitates the process of knowledge dissemination, mutual learning and adaptation via the effects of 'knowledge spillovers' (Breschi and Lissoni, 2001; Caragliu and Nijkamp, 2016) and 'innovation diffusion' (Rogers, 2003). Region in this context is a scale and space for economic interactions and innovation activity, as well as a source of strategic resources for businesses: specialized labour market, network of suppliers and subcontractors, particular institutional infrastructure, etc. However, continuous innovative growth provision of regional firms is not limited to localization of economic activity. As proven by numerous studies, innovation capacity diminishes over time due to the alignment of technological development levels in the process of mutual learning that creates 'technological lock-in' (Witt, 1997) (also known as 'cognitive lock-in' (Thrane et al., 2010) or 'competency trap' (Akgün et al., 2007) taking a broader perspective of knowledge proximity). Overcoming this effect by regional firms is associated with the search for additional channels of information, accessing which enables to maintain the desired diversity level of knowledge, competencies, technologies, information circulating within the regional system - the 'cross-fertilization', and provides a further innovation development. Thus, innovation activities of regional companies within the first approach are considered in two aspects: on the one hand, - clustering of economic entities (i.e. their localization and concentration) and the establishment of a favourable surrounding (i.e. inventive-enabling, empowering, inspiring, fertile), and on the other - the participation of local actors in the networks beyond localized interactions 
capturing heterogeneous actors from outside the region, i.e. the extra-local networking via Amin and Thrift's 'network nodes' (1992), or the 'global pipeline' actors as put by Bathelt et al. (2004).

The second approach is characterized by the perception of innovation activity as a social process, which is formed due to various institutional routines and social agreements (Alic et al., 1992; Morgan, 1997). The agglomeration economies of spatially proximate actors are enriched by what Becattini $(1989$, p.38) has called a relationship between the "community of people and a population of firms", leading to the emergence of certain innovation environment formed by the daily social intercourse. Rootedness or embeddedness of such socio-economic relations in a particular area is influenced by the regional context, which is a set of norms and rules of behaviour that have emerged under the influence of economic and socio-cultural factors. The accumulation of social capital in regional networks enables to create a relationship based on trust and a sense of belonging to a single regional community (or 'territorial community' featuring professional associations - 'communities of practice'), which greatly facilitates the exchange of knowledge and information between market participants, and eventually helps to reduce costs and uncertainty (Brown and Duguid 1991; Camagni, 1991; Mezhevich, 1978; Stephanopoulos, 2012; Wolfe, 2002). Thus, an important social aspect of innovation is to assist mutual learning between regional (i.e. local) and external actors, which is affected by the complex of internal and external intangible factors defined by Storper (1997).

The innovation potential of various actors is determined by their ability to detect, disclose, adapt and use new knowledge that is to learn. The ability to learn reflects the dynamics and cooperative relations of organizations, their adaptation to changing environmental conditions and different contextual factors (Camagni, 1991; Cooke and Morgan, 1993; Fomina et al., 2018; Kirat and Lung, 1999; Sorenson et al., 2006). Meanwhile company is not regarded as an isolated agent of innovation, but as stakeholder of collective learning (Rauter et al., 2017), and as part of the locus with its own innovation potential (Moulaert and Sekia, 2003). Studying the issues of regional development in the context of globalization, Storper (1997) drew attention to the importance of organizational and technological learning within agglomerations, based on the non-commercial, 'untraded interdependences': foundations, values, norms, institutions. The European concept of innovation milieu acts as an umbrella for the research on the role of endogenous institutional capacity in the emergence of highly innovative companies (e.g. see Aydalot, 1986). Regional development is found to be highly related to the creation of favourable innovative environment; i.e. the institutional setup that favours long-term risk investment (incl. those in R\&D, modernization of fixed assets, staff advanced training, etc.). Often these advantages are given to particular territories or largescale projects. Typically, these are the technological and knowledge sites (i.e. clusters, S\&T parks, technopoles, etc.) that concentrate regional resources and are characterized by a variety of actors involved. Their essence is to provide the conditions necessary and sufficient for the establishment of a unique milieu that would enable to locally ensure the effective implementation of learning and innovation processes. Integration of distinct innovation systems over the border places a particular emphasis on innovation security domain of regional innovation policy.

\section{Research methodology}

The research scope covers an area of 48 European states, including the 28 countries of the European Union (EU), the partially recognized states of Kosovo and Pridnestrovie (Transnistria), and the European part of Russian. The total number of 218 border regions corresponding to second level of a common classification of territorial units for statistics (NUTS 2) of the European Commission (2015) is analysed. These includes a list of 160 cross-border regions, 23 European grouping of territorial cooperation, and 17 large-scale cross-border cooperation domains as defined by the Association of European Border Regions (AEBR). The research methodology has a two-stage structure. The first stage is the general assessment that incorporates open-source data on international projects in the borderland directed at intensification of economic and innovation activity, SME competitiveness (e.g. projects 
The International Journal

ENTREPRENEURSHIP AND SUSTAINABILITY ISSUES

ISSN 2345-0282 (online) http://jssidoi.org/jesi/

2018 Volume 6 Number 2 (December)

http://doi.org/10.9770/jesi.2018.6.2(19)

of the European Territorial Cooperation (ETC) programmes, the Pre-Accession Assistance (IPA) and the Connecting Europe Facility (CEF) Pan-European instruments). An overview is made over cross-border initiatives focused on establishment of cross-border clusters and/or a common innovation infrastructure (e.g. science and technology park, technopolis, etc.). The data sources are the European Cluster Observatory, the European Cluster Collaboration Platform, the Global practitioners network for competitiveness, clusters and innovation (TCI), as well as national platforms with information on regional clusters, innovation activity and cross-border networking (e.g. the Russian Cluster Observatory, public agencies for industry and innovation). The study implies floating timeline by integrating all of the data available, giving emphasis to completed projects.

The second stage implies an in-depth analysis of a selection of remarkable experiences in implementation of cross-border cooperation projects initiated at least ten years ago. The retrospective approach is necessary to provide enough data and expert opinions of project managers, scholars, public officials on the results achieved (incl. the intermediate results). The identified sample is classified into identified types of general development threats to innovation security for regional innovation systems of the borderland. Research results present one brief case study per each type allocated. The general objective is to summarize and classify the possible variations in the deployment of cross-border cooperation actions with a particular emphasis on the threats to regional and/or national innovative milieus.

\section{Research findings}

The highest intensity of cooperation across national borders is being naturally found within the single space of the European Union (EU). The internal border areas are being increasingly integrated in socio-cultural, economic, infrastructural, political, and other spheres with an assistance of pan-European funding (incl. Interreg instrument of the European Cohesion policy). Moreover, the cross-border regional innovation systems integration initiatives between the borderland areas of the EU states are generally more mature (i.e. are initiated 10 and more years ago). Figure 1 shows the schematically represented process of cross-border regional innovation system formation. It should be noted that cross-border regional innovation system (CBRIS) is defined as a system that unites firms and organizations of various types systematically involved in the interactive learning process, rooted in the institutional environment of an area of adjacent territories belonging to different nation-states. 


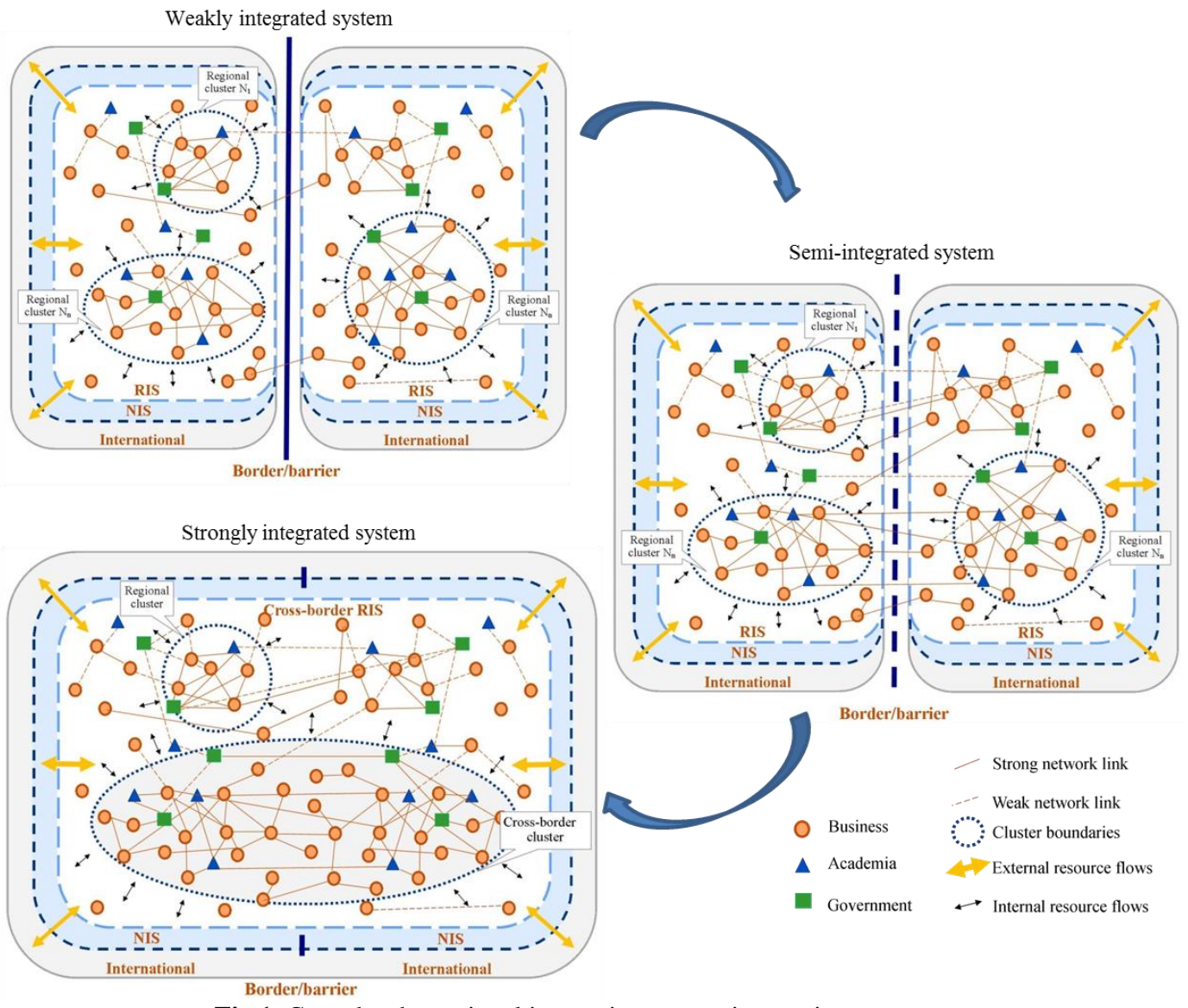

Fig.1. Cross-border regional innovation system integration stages

Source: based on stages classification suggested by Lundquist and Trippl (2011)

Weakly integrated systems are commonly found outside the EU, incl. its external borders (e.g. the WarmianMasurian voivodeship of Poland and the Kaliningrad region of Russia). These regions have security checkpoints at their border crossings and the barrier function of the border dominates over the contact one. Least integrated are regions with potential, smoldering or active conflicts. Mostly these are borderland areas in Eastern Europe, such as the Balkan Peninsula. Semi-integrated systems are most widespread, as they naturally evolve in the common space of the European Union, as well as Switzerland and Norway. Strongly integrated systems are rare, as they imply significant coherence of the borderland and the synchronization of regional innovation systems (incl. knowledge generation, exploitation and subsystems).

High integrity of regional innovation systems result in numerous positive externalities, such as positive dynamics in new firm creation (incl. university spin-offs, start-ups, MNC subsidiaries), especially in high-tech sector; growing variety of industry sectors (e.g. ICT, biotechnology, nanotechnology, food, environmental technologies, creative industries, logistics, etc.); growth in FDI volume, increased private expenditure on R\&D; GDP growth and productivity; decrease of unemployment figures and increase in average annual salary; increase in market diversification, involvement in global value chains; influx of qualified workforce; infrastructure development, etc. The best practice include the cross-border regions of Oresund (Denmark - Sweden), Upper Rhine (France Germany - Swizerland), Bothnian Arc (Sweden - Finland). Notwithstanding the aforementioned benefits to 
regional development, strong integrity of the borderland may be harmful in case of internal asymmetries or rapid disintegration of ties.

Asymmetry in the formation and development of a cross-border innovative milieu has a two-fold manifestation. First is the gradual transition of innovative milieu of the less influential region towards the socio-economically superior territory. This process is accompanied by partial exclusion from national innovation system or the priority shift in partnership network towards the adjacent borderland. One clear example is the Scania region of Sweden. Over the past ten years this region expresses functional disintegration from the Swedish national innovation system of ties, placing national interregional integrity at a threat. Its spatial proximity to Copenhagen metropolitan area (the capital city of Denmark) as well as the functional complementarity in medical biotechnology specialisation has resulted in natural unification of the two regional innovation systems (Fig. 2). This cross-border integration was boosted in the new millennium with the construction of the Oresund Bridge, which sharply increased the volume of daily commutes across national borders.

1998 2018

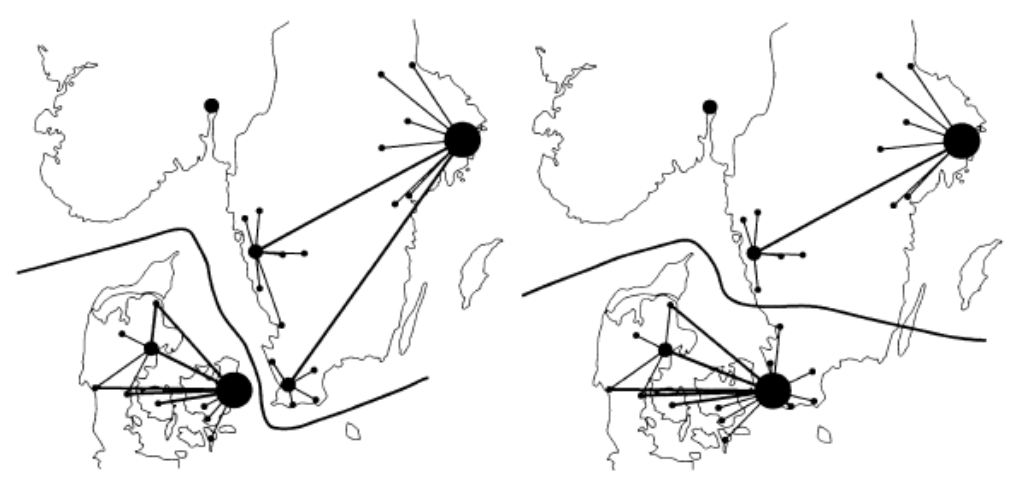

Fig.2. Rearrangement of the Swedish national innovation system

Source: adopted from Matthiessen (2000)

Second pattern is the initial domination of one counterpart over the other in terms of available resources (e.g. financial, administrative) supporting the long-term development scenario set. The general benefits of cross-border cooperation and integration are often being evaluated from the short-term perspective. Underestimation of the long-term effect can reduce the efficiency of regional development policies and even harm national innovation system. A particular example may be Limburg (Netherlands) - North Rhine-Westphalia (German) borderland region (Fig. 3). Active deployment of cross-border cooperation initiatives has brought numerous positive externalities; however, differences in strategic priorities of long-term development meant that the distribution of these benefits is uneven. Dutch smart specialization strategy for Southern Netherland fully corresponds with the horticultural specialization of Venlo, focusing the efforts of local municipalities (e.g. the Greenport Venlo initiative). Different situation is found to be on the German side of the border, where the strategic priority lies within high-tech industries. Innovation policy of the federal state is not aligned with ongoing sectoral focus on horticulture (driven by the Dutch counterpart), thus, reduces the efficiency of national measures undertaken. 


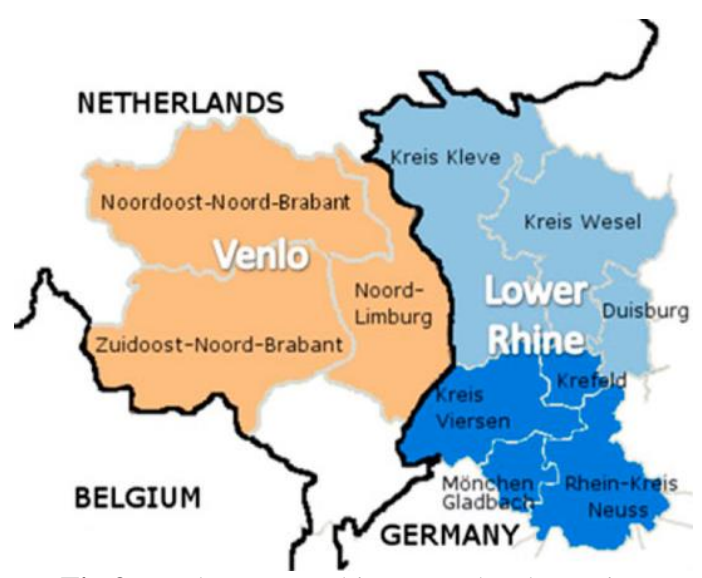

Fig.3. Venlo-Lower Rhine cross-border region

Source: adopted from Broek and Smulders (2015)

Divergence of the cross-border regional innovation system leads to unilateral outflow or unbalanced exchange of ideas, knowledge, and technologies, where one region becomes a donor and the other accumulates all the significant competitive competencies in the innovation sphere. The possible consequences of the peripheral region are (incl. industry sector-wise): strong technological, infrastructural, financial, personnel and other dependencies; environmental, ethical, social issues due to legislation flaws (e.g. legislation gap on animal experiments, ecological standards, labour rights, etc.); investment outflow and brain drain to adjacent border region hosting major stages of the innovation process (e.g. research, design, etc.); resources allocation in areas not corresponding national long-term development priorities; growth of political and economic influence of neighbouring country on regional development; unequal resource input in research collaboration (incl. loss of unique rights to inventions resulting from previously undertaken basic science research), etc.

Disruption of previously established networks (e.g. industrial, research, technological, educational, social, cultural) that form the core on a single transboundary regional innovation system is a serious challenge for both adjacent territories. Although this may be affected by macroeconomics (e.g. the global technological shift; such as change in the focus from raw materials, such as coal), all of the recent examples of decay are driven by geopolitics. Of all the changes occurred over the past decade, the collapse of Russian - Ukrainian long-lasting value chains has the greatest impact in the scope of Europe. The innovative milieu established over the long period of time had gained significant fragility in socio-cultural terms. Rapid distortion of a single value chain generated isolated actors with incomplete competences on both sides of the border, and developed conditions for the following threats: structural holes along the value chain (loss of partners with complementary competencies supplementary or critical in nature); difficulties accessing external resources - HR, finance, technology, etc., and infrastructure - industrial, energy, transport, logistics, etc.; brain drain, closure of complex research projects, limited R\&D funding; increased expenses on foreign technologies, equipment, licenses, etc.; limited access to foreign education, health care, cultural amenities; institutional system collapse (e.g. norms, regulations), etc.

Enclosed attitude towards the development of a cross-border innovative milieu implies unilateral integration initiatives, i.e. the course on closeness (even latent) by one of the adjacent regions, showing lack of desire for transboundary integration. Territories of this type of borderland have occasional, episodic, 'shallow' interactions, not implying joint creation of new knowledge (R\&D or fully-flagged S\&T cooperation). Relations of the regional innovation systems are reduced to foreign trade and episodic academic contacts (e.g. individual academic mobility, seldom co-authorship, etc.). This type of relations are rarely beneficial to either borderland areas, but are found to be widespread outside EU due to general market protection measures (e.g. the entire borderland of 
The International Journal

ENTREPRENEURSHIP AND SUSTAINABILITY ISSUES

ISSN 2345-0282 (online) http://jssidoi.org/jesi/

2018 Volume 6 Number 2 (December)

http://doi.org/10.9770/jesi.2018.6.2(19)

Belarus, European part of Russia, Ukraine, etc.). In terms of regional innovation security of the borderland these measures limit the variety of trade partners and specialized business services provided; decrease the volume of $\mathrm{R} \& \mathrm{D}$ expenditure by foreign entities; fragmentize and restrict embeddedness of the innovation process; reduce numbers of joint implementation of innovative projects and collaborative R\&D; obstruct labour mobility and create social closeness; create cultural and ideological disunity of the borderland, foster differences in mentality and traditions; increase the dependence of regional innovation processes on unique innovative infrastructure of neighbouring states or, on the contrary, create complete infrastructural isolation (i.e. in case of absence of certain S\&T infrastructure, logistics, etc.).

\section{Conclusions}

Strategic cross-border coupling of innovative milieus is a complex task, not least due to semi-peripheral status of many borderland areas. Adherence of the two distinct regional innovation systems requires all-embracing attention of public authorities with regard to sustaining optimal balance of national innovation system integrity and transboundary coherence. Regional socio-economic divergence is a particular factor fostering unequal distribution of roles within a single cross-border regional innovation system. Actors of less favourable borderland in terms of legislation, infrastructure, funding opportunities, human capital, etc. are subjected to development priorities of the networking counterpart across border. Being neglected this problem may result in the shift of R\&D subject area, change in specialisation, intellectual resources outflow, etc., decreasing the input value of local territorial capital in national accounts. The extreme scenario would be rearrangement of the national innovation system with alienation of the region's innovation system. Efficient place-sensitive regional innovation policy can strengthen the innovation profile of the region by achieving synergies from combining resources across state border. The missing elements of the complex cluster categories are to be sourced externally, while the smart specialisation strategy has to support the enhancement of local strengths. Oresund region is the best practice of establishing an internationally competitive cross-border regional innovation system based on complementary competitive advantages in biotechnology, medicine and pharmaceuticals.

As noted by Tvaronavičienè and Černevičiūtė (2015), knowledge and technology transfer is highly related to the willingness of doing so. Our study results suggest that internationalization of regional innovative milieu over the borderland area can confront numerous restrictions at any stage of the lifecycle. The strongest restriction for sustainable collaboration is unfavourable geopolitics. Thus, a significant part in the formation of a favourable innovation environment takes the elaboration, approval and implementation of a regional innovation strategy for long-term development, being shared by major stakeholders at both sides of the border. The strategy should reflect and consistently promote the image of the region in the future. Its achievement is based on the identified strengths and is consistent with its current capabilities and cultural characteristics.

An essential role in creating and maintaining a desired innovation environment is given to the process of increasing the interactivity and openness of regional innovation processes. Increase of interactivity presumes the involvement of business, government, academia representatives and the general public in innovation process on a systematic basis in order to identify and jointly resolve common regional problems, as well as to organize new and improve the effectiveness of existing channels and processes of cooperation and information exchange. Increasing the openness of transboundary innovative milieu is associated with increase in informal extra-regional interactions, including through mobility of labour resources, scientific and student mobility, preparing the economy to the entry of new companies and ideas, adopting cultural diversity, supporting internationalization processes in the region.

Regional innovation policy should account for the following important factors affecting sustainability of regional innovative milieu across borders: the presence of a common vision among stakeholders, enshrined in the strategy 
of innovative development of the cross-border regional innovation system; a high level of innovative business activity and the desire to share and adopt knowledge; formation of an atmosphere of innovative entrepreneurship (i.e. risk encouragement); the possibility of informal contacts and information exchange between employees of various companies; availability of mechanisms for interaction between the three institutional helices - the government authorities, academic research and business sectors; institutional assistance to the development of various forms of networking.

\section{References}

Akgün, A.E., Byrne, J.C., Lynn, G.S., Keskin, H. 2007. Organizational unlearning as changes in beliefs and routines in organizations, Journal of Organizational Change Management 20(6): 794-812. DOI: http://dx.doi.org/10.1108/09534810710831028

Alic, J.A., Branscomb, L.M., Brooks, H., Carter, A.B., Epstein, G.L. 1992. Beyond Spin-off: Military and Commercial Technologies in a Changing World, Harvard College, Cambridge MA.

Almeida, P., Kogut, B. 1997. The Exploration of Technological Diversity and the Geographic Localization of Innovation, Small Business Economics 9(1): 21-31.

Amin, A., Thrift, N. 1992. Neo-Marshallian Nodes in Global Networks, International Journal of Urban and Regional Research 16(4): 571-587. DOI: http://dx.doi.org/10.1111/j.1468-2427.1992.tb00197.x

Audretsch, D.B., Feldman, M.P. 2004. Knowledge Spillovers and the Geography of Innovation, in Henderson, J.V. Thisse J.-F. (Eds.). Handbook of Regional and Urban Economics, Vol. 4, 2713-2739. DOI: https://doi.org/10.1016/S1574-0080(04)80018-X

Aydalot, P. 1986. Milieux Innovateurs en Europe, GREMI, Paris.

Baburin, V.L., Zemtsov, S.P. 2014. Regions-innovators and innovative periphery of Russia. Study of ICT-products diffusion, Regional Studies 3(45): 27-38.

Bathelt, H., Malmberg, A., Maskell, P. 2004. Clusters and knowledge: local buzz global pipelines and the process of knowledge creation progress, Human Geography 28(1): 31-56. DOI: http://dx.doi.org/10.1191/0309132504ph469oa

Becattini, G. 1989. Riflessioni sul distretto industriale marshalliano come concetto socio-economico, Statoe Mercato 25(1): 111-128.

Bergek, A., Berggren, C., Magnusson, T., Hobday, M. 2013. Technological discontinuities and the challenge for incumbent firms: Destruction, disruption or creative accumulation?, Research Policy 42(6-7): 1210-1224. DOI: http://dx.doi.org/10.1016/j.respol.2013.02.009

Breschi, S., Lissoni, F. 2001. Knowledge spillovers and local innovation systems: a critical survey, Industrial and Corporate Change 10(4): 975-1005. DOI: http://dx.doi.org/10.1093/icc/10.4.975

Broek J., Smulders H. 2015. Institutional hindrances in cross-border regional innovation systems, Regional Studies, Regional Science 2(1): 116-122, DOI: http://dx.doi.org/10.1080/21681376.2015.1007158

Brown, J.S., Duguid, P. 1991. Organizational learning and communities of practice: toward a unified view of working, learning and innovation, Organization Science 2(1): 40-57. DOI: http://dx.doi.org/10.1287/orsc.2.1.40

Camagni, R. 1991. Introduction: from the local milieu to innovation through cooperation networks, in Camagni, R. (Ed.). Innovation networks: spatial perspectives, Belhaven Press, London, 1-9.

Caragliu, A., Nijkamp, P. 2016. Space and knowledge spillovers in European regions: the impact of different forms of proximity on spatial knowledge diffusion, Journal of Economic Geography 16(3): 749-774. DOI: http://dx.doi.org/10.1093/jeg/lbv042 
Carlsson, B., Jacobsson, S., Holmen, M., Rickne, A. 2002. Innovation systems: Analytical and methodological issues, Research Policy 31(2): 233-245. http://dx.doi.org/10.1016/S0048-7333(01)00138-X

Cooke, P., Morgan, K. 1993. The Network Paradigm: New Departures in Corporate and Regional Development, Environment and Planning D: Society and Space 11: 543-564.

Eliasson, G. 1996. Spillovers, integrated production and the theory of the firm, Journal of Evolutionary Economics 6(2): 125-140. DOI: http://dx.doi.org/10.1007/BF01202590

European Commission. 2015. Regions in the European Union: Nomenclature of territorial units for statistics NUTS 2013/EU-28, Luxembourg: Publications Office of the European Union. Available on the Internet: http://ec.europa.eu/eurostat/documents/3859598/6948381/KS-GQ-14-006-EN-N.pdf

Feldman, M.P., Audretsch, D.B. 1996. Location, Location, Location: The Geography of Innovation and Knowledge Spillovers. Discussion Paper FS IV. Berlin: Wissenschaftszentrum, 96-28. Available on the Internet: http://bibliothek.wz-berlin.de/pdf/1996/iv96-28.pdf

Fomina, A.V. Berduygina, O.N., Shatsky, A.A. 2018. Industrial cooperation and its influence on sustainable economic growth, Entrepreneurship and Sustainability Issues 5(3): 467-479. https://doi.org/10.9770/jesi.2018.5.3(4)

Gertler M., Wolfe, D., Garkut, D. 2000. No Place like Home? The Embeddedness of Innovation in a Regional Economy, Review of International Political Economy 7(4): 688-718.

Hall, J.K., Martin, M.J.C. 2005. Disruptive technologies, stakeholders and the innovation value-added chain: A framework for evaluating radical technology development, $R$ and D Management 35(3): 273-284. DOI: http://dx.doi.org/10.1111/j.1467-9310.2005.00389.x

Huggins, R., Johnston, A. 2009. Knowledge networks in an uncompetitive region: SME innovation and growth, Growth and Change 40(2): $227-259$.

Kirat, T., Lung, Y. 1999. Innovation and proximity - territories as loci of collective learning processes, European Urban and Regional Studies 6(1): 27-38. http://dx.doi.org/10.1177/096977649900600103

Lagendijk, A., Lorentzen, A. 2007. Proximity, knowledge and innovation in peripheral regions: on the intersection between geographical and organizational proximity, European Planning Studies 15(4): 457-466.

Lundquist, K.-J., Trippl, M. 2011. Distance, Proximity and Types of Cross-border Innovation Systems: A Conceptual Analysis, Regional Studies 47(3): 450-460. DOI: http://dx.doi.org/10.1080/00343404.2011.560933

Maskell, P., Malmberg, A. 1999. The competitiveness of firms and regions. "Ubiquitification" and the importance of localized learning, European Urban and Regional Studies 6(1): 9-25.

Matthiessen C.W. 2000. Bridging the Oresund: potential regional dynamics Integration of Copenhagen (Denmark) and Malmo-Lund (Sweden) A cross-border project on the European metropolitan level, Journal of Transport Geography 8: 171-180

Melançon, Y., Doloreux, D. 2013. Developing a knowledge infrastructure to foster regional innovation in the periphery: a study from Quebec's coastal region in Canada, Regional Studies: 47(9): 1555-1572. DOI: http://dx.doi.org/10.1080/00343404.2011.626400

Mezhevich, M.N. 1978. Territorial community of people and social development under socialism, Sociological studies 3: 31.

Mikhaylov, A.S. 2016. An integrated approach to delimitation and demarcation of a spatial network boundary, International journal of economic research: 13(7): 2719-2734.

Mikhaylova, A.A., Mikhaylov, A.S. 2015. Instruments of innovation security, International Journal of Economics and Financial Issues 2(5): 128-135. 
Mikhaylova, A.A., Mikhaylov, A.S. 2016. Re-distribution of knowledge for innovation around Russia, International Journal of Technological Learning, Innovation and Development 8(1): 37-56. http://dx.doi.org/10.1504/IJTLID.2016.075179

Morgan, K. 1997. The learning region: institutions, innovation and regional renewal, Regional Studies 31(5): 491-503.

Morrissey, K. 2015. An inter and intra-regional exploration of the marine sector employment and deprivation in England, The Geographical Journal 181(3): 295-303. DOI: http://dx.doi.org/10.1111/geoj.12099

Moulaert, F., Sekia, F. 2003. Territorial Innovation Models: A Critical Survey, Regional Studies 37(3): $289-302$.

Niosi, J. 2000. Regional systems of innovation: market pull and government push. Paper presented at the Annual meeting of the Canadian Research Network on Regional Innovation Systems. May 2000. Montreal, Canada.

Oerlemans, L., Meeus, M., Boekema, F. 2001. On the spatial embeddedness of innovation networks: an exploration of the proximity effect, Tijdschrift voor economische en sociale geografie 92(1): 60-75. DOI: http://dx.doi.org/10.1111/1467-9663.00139

Rauter, R., Perl-Vorbach, E., Baumgartner, R.J. 2017. Is open innovation supporting sustainable innovation? Findings based on a systematic, explorative analysis of existing literature, International Journal of Innovation and Sustainable Development 11(2-3): 249-270. DOI: http://dx.doi.org/10.1504/IJISD.2017.083289

Rogers, E.M. 2003. Diffusion of innovations, $5^{\text {th }}$ ed. New York: Free Press.

Sorenson, O., Rivkin, J.W., Fleming, L. 2006. Complexity, networks and knowledge flow, Research Policy 35(7): 994-1017. http://dx.doi.org/10.1016/j.respol.2006.05.002

Stephanopoulos, N. 2012. Redistricting and the Territorial Community, University of Pennsylvania Law Review 160: $1379-1477$.

Storper, M. 1995. The resurgence of the regional economies ten years later: the region as a nexus of untraded interdependencies, European Urban and Regional Studies 2(3): 191-215. DOI: http://dx.doi.org/10.1177/096977649500200301

Storper, M. 1997. The Regional Economy: Territorial Development in a Global Economy. New York, London: Guilford Press,.

Thrane, S., Blaabjerg, S., Møller, R.H. 2010. Innovative path dependence: Making sense of product and service innovation in path dependent innovation processes, Research Policy 39(7): 932-944. DOI: http://dx.doi.org/10.1016/j.respol.2010.04.003

Tödtling, F., Trippl, M. 2005. One size fits all?: towards a differentiated regional innovation policy approach, Research Policy 34(8): $1203-1219$.

Tvaronavičienė, M., Černevičiūtè, J. 2015. Technology transfer phenomenon and its impact on sustainable development, Journal of Security and Sustainability Issues 5(1): 87-97. DOI: $\underline{\text { http://dx.doi.org/10.9770/jssi.2015.5.1(7) }}$

Virkkala, S. 2007. Innovation and networking in peripheral areas - a case study of emergence and change in rural manufacturing, European Planning Studies 15(4): 511-529. DOI: http://dx.doi.org/10.1080/09654310601133948

Witt, U. 1997. "Lock-in" vs. "critical masses" - Industrial change under network externalities, International Journal of Industrial Organization 15(6): 753-773. DOI: http://dx.doi.org/10.1016/S0167-7187(97)00010-6

Wolfe, D.A. 2002. Knowledge, Learning and Social Capital in Ontario's ICT Clusters. Paper presented at the Annual Meeting of the Canadian Political Science Association University of Toronto. 29-31 May 2002. Toronto, Canada. 
The International Journal

ENTREPRENEURSHIP AND SUSTAINABILITY ISSUES

ISSN 2345-0282 (online) http://jssidoi.org/jesi/

2018 Volume 6 Number 2 (December)

http://doi.org/10.9770/jesi.2018.6.2(19)

\section{Aknowledgements}

The reported study was funded by Russian Science Foundation according to the research project 18-17-00112 "Ensuring economic security of Russia's western border regions in the conditions of geopolitical turbulence";

The publication has been prepared with the partial support of the "RUDN University Programme "5-100"»

Andrey S. MIKHAYLOV is the senior research fellow at the Institute of Environmental Management, Urban Development and Spatial Planning, Immanuel Kant Baltic Federal University Kaliningrad, Russian Federation. Dr. Mikhaylov is the graduate of Karlstad University (Sweden) and holds a doctoral degree in human geography. His research is devoted to the issues of socio-spatial divergence, inter- and intraregional inequalities and spatially targeted regional policies.

ORCID ID: orcid.org/0000-0002-5155-2628

Anna A. MIKHAYLOVA is the research fellow at the Institute of Environmental Management, Urban Development and Spatial Planning, Immanuel Kant Baltic Federal University Kaliningrad, Russian Federation. Dr. Mikhaylova is the graduate of Kaliningrad State Technical University (Russia) and holds a doctoral degree in human geography. Her research focus is in innovation geography with a special emphasis on innovation security concept.

ORCID ID: orcid.org/0000-0002-6807-6074

Oksana V. SAVCHINA is the associate professor at the Faculty of Economics, Peoples' Friendship University of Russia, Moscow, Russian Federation. Dr. Savchina is the graduate of RUDN University and holds a doctoral degree in economics. Her research focus is in macroeconomic instability with a special emphasis on financial sustainability.

ORCID ID: https://orcid.org/0000-0003-3568-576X

Copyright (C) 2018 by author(s) and VsI Entrepreneurship and Sustainability Center

This work is licensed under the Creative Commons Attribution International License (CC BY).

http://creativecommons.org/licenses/by/4.0/

c) (7) Open Access 